\title{
LETTERS
}

\section{Peripheral ulcerative keratitis in rheumatoid arthritis: successful use of intravenous cyclophosphamide and comparison of clinical and serological characteristics}

\author{
A R Clewes, J K Dawson, S Kaye, R C Bucknall
}

Ann Rheum Dis 2005;64:961-962. doi: 10.1136/ard.2004.023283

$P$ eripheral ulcerative keratitis (PUK) is a devastating complication of rheumatoid arthritis (RA) that can lead to rapid corneal destruction (corneal melt) and perforation with loss of vision (fig l). It is well reported to herald systemic vasculitis and carries a high mortality rate if not aggressively treated. ${ }^{1}$ There is a paucity of information concerning the clinical and serological characteristics of these patients and no clear consensus about treatment.

We report the successful management of seven such patients with the use of intravenous cyclophosphamide and compare the serological and clinical characteristics with a comparative group of 150 rheumatoid patients without associated PUK, who attended an outpatient clinic.

\section{CASE REPORTS}

All patients received systemic immunosuppressive treatment with intravenous cyclophosphamide and the dose was dependent on age, weight, renal function, and clinical response. All received some form of adjunctive ocular treatment including cyanoacrylate glue, bandage contact lenses, punctual occlusion, and corneal transplants. Two patients also received intravenous corticosteroid treatment with $1 \mathrm{~g}$ methylprednisolone (table 1).

Student's $t$ test was used to compare the melt and comparative groups, the Mann-Whitney $U$ test to compare quantitative data, and a $\chi^{2}$ squared test with Fisher's exact test to compare frequencies. No difference in duration of disease, presence of rheumatoid nodules, Sjögren's syndrome, or seropositivity for rheumatoid factor was found between the groups. Disease activity did not correlate with ocular disease and there was no active synovitis at

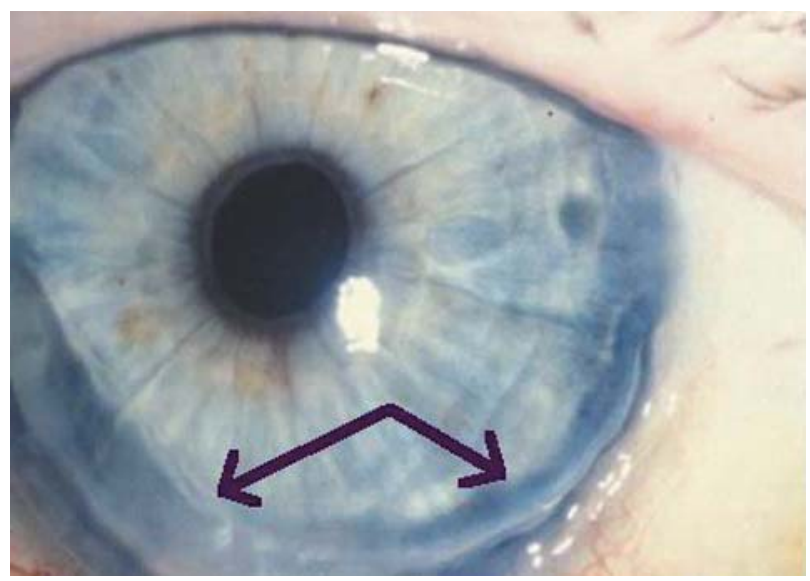

Figure 1 Note the peripheral circumferential damage from corneal ulceration (arrows). presentation. The melt group were older (median age $71.9 \mathrm{v}$ 58.9 years, $p=0.013)$ and were more inclined to be antinuclear antibody (ANA) positive $(\mathrm{p}=0.03)$. Serum albumin levels were statistically lower $(36.7 \mathrm{~g} / \mathrm{l} \vee 40.83 \mathrm{~g} / \mathrm{l}, \mathrm{p}=0.012)$ and immunoglobulin levels polyclonally increased $(\operatorname{IgA} 3.62 \mathrm{v}$ $2.80 \mathrm{~g} / \mathrm{l}, \mathrm{p}=0.035 ; \operatorname{IgG} 3.93 v 1.42 \mathrm{~g} / \mathrm{l}, \mathrm{p}=0.001 ; \operatorname{IgM} 16.74 v$ $10.97 \mathrm{~g} / \mathrm{l}, \mathrm{p}=0.005)$. A previous history of scleritis seemed to correlate with increased risk of PUK $(p=0.002)$, but the presence of sicca disease did not reach significance $(\mathrm{p}=0.165)$.

\section{DISCUSSION}

No correlation between articular activity and PUK was found, but there was a statistically significant association with the presence of ANA, raised immunoglobulins, and reduced albumin concentrations when compared with the comparative group. This may represent increased subclinical disease activity. The pathogenic mechanisms behind PUK are still unclear but whatever the mechanisms, the important issue is that this condition needs aggressive treatment with immunosuppression. $^{1-8}$ Foster et al compared the outcome of 34 patients with rheumatoid associated necrotising scleritis and PUK, half of whom received systemic immunosuppressive treatment and half non-immunosuppressive topical conventional treatment. In those not receiving immunosuppression, vasculitis developed in more than $50 \%$ of cases with a high mortality rate. ${ }^{1}$ Jayson and Jones, ${ }^{2}$ Mcavin et al, ${ }^{3}$ and Watson and Hayreh ${ }^{4}$ also suggested that these aggressive destructive ocular lesions herald systemic vasculitis and require aggressive immunosuppressive treatment. Azathioprine, ${ }^{56}$ methotrex$a^{2},^{78}$ and ciclosporin ${ }^{8}$ have been used with varying success, but cyclophosphamide ${ }^{169}$ has been widely used in destructive ocular inflammatory conditions and has a well established role in treating systemic vasculitis. ${ }^{10}$ Systemic and local steroids are used but we have concerns about the reduction in cornea healing, and steroids alone do not alter mortality.

We found no incidence of infection or immunosuppressive complication. The vision of all patients was preserved and, to date, none of the patients who received intravenous cyclophosphamide have presented with evidence of systemic vasculitis and this is probably due to the use of immunosuppressive treatment.

We cannot emphasise enough that this is a condition that should be managed by both a rheumatologist and an ophthalmologist, both of whom need to be aware of the acute ocular concerns as well as the long term consequences with associated high mortality in those who do not receive immunosuppressive treatment. ${ }^{1-4}$

\section{Authors' affiliations}

A R Clewes, R C Bucknall, Rheumatic Diseases Unit, Royal Liverpool University Hospital, Liverpool, UK 
Table 1 Summary of characteristics

\begin{tabular}{|c|c|c|c|c|c|c|c|c|c|c|}
\hline Patient & Eye & Age† (years) & Sex & $\begin{array}{l}\text { Duration of } \\
\text { RA } \ddagger \text { (years) }\end{array}$ & $\begin{array}{l}\text { Sjögren's } \\
\text { disease }\end{array}$ & Nodules & RF & ANA & $\begin{array}{l}\text { Duration of } \\
\text { meltqा (weeks) }\end{array}$ & $\begin{array}{l}\text { IV Cyclophosphamide (total } \\
\text { dose in } \mathrm{mg} \text { ) }\end{array}$ \\
\hline 1 & Left & 89 & $\mathrm{~F}$ & 22 & No & Yes & + & + & 6 & 2000 \\
\hline 2 & Both & 71 & $\mathrm{~F}$ & 7 & Yes & Yes & + & - & 9 & 4500 \\
\hline $3^{*}$ & Right & 64 & M & 10 & No & No & + & + & 3 & 1000 \\
\hline 4 & Left & 87 & $\mathrm{~F}$ & 20 & Yes & No & - & + & 2 & 500 \\
\hline 5 & Right & 50 & $\mathrm{~F}$ & 2 & No & Yes & + & + & 6 & 3000 \\
\hline 6 & Right & 67 & $\mathrm{~F}$ & 2 & Yes & No & - & + & 2 & 1000 \\
\hline $7^{*}$ & Left & 75 & $M$ & 11 & Yes & Yes & - & + & 4 & 750 \\
\hline
\end{tabular}

${ }^{*} 1 \mathrm{~g}$ methylprednisolone given; tmean (SD) age 71 (13) years; łmean (SD) duration of RA 10.5 (8) years; 9 mean (SD) duration of melt 4.2 (2.5) weeks.

J K Dawson, Department of Rheumatology, St Helens and Knowsley Hospitals NHS Trust, St Helens, Merseyside, UK S Kaye, Department of Ophthalmology, St Paul's Eye Unit, Royal Liverpool University Hospital, Liverpool, UK

Correspondence to: Dr A R Clewes, Rheumatic Diseases Unit, Link 7c, Royal Liverpool University Hospital, Prescot Street, Liverpool, L7 8XP, UK; adrian@aclewes.freeserve.co.uk

Accepted 9 October 2004

\section{REFERENCES}

1 Foster CS, Forstot SL, Wilson LA. Mortality rate in rheumatoid arthritis patients developing necrotizing scleritis or peripheral ulcerative keratitis; effects of systemic immunosuppression. Ophthalmology 1984;91:1253-63.

2 Jayson MI, Jones DE. Scleritis and rheumatoid arthritis. Ann Rheum Dis $1971 ; 30: 343-7$.
3 McGavin DDM, Williamson J, Forrester JV, Foulds WS, Buchanan WW, Dick WC, et al. Episcleritis and scleritis; a study of their clinical manifestations and association with rheumatoid arthritis. Br J Ophthalmol 1976;60:192-226.

4 Watson PG, Hayreh SS. Scleritis and episcleritis. Br J Ophthalmol 1976:60:163-91.

5 Squirrel DM, Winfield J, Amos RS. Peripheral ulcerative keratitis 'corneal melt' and rheumatoid arthritis: a case series. $\mathrm{Br} J$ Rheumatol 1999;38: 1245-8.

6 Jifi-Bahool H, Saadeh C, O'Connor J. Peripheral ulcerative keratitis in the setting of rheumatoid arthritis: treatment with immunosuppressive therapy. Semin Arthritis Rheum 1995:25:67-73.

7 Foster CS. Immunosuppressive therapy for external ocular inflammatory disease. Ophthalmology 1980;87:140-9.

8 Bernaver W, Watson P. The management of corneal perforations associated with rheumatoid arthritis: an analysis of 32 eyes. Ophthalmology 1995: 102:1325-37.

9 Sule A, Balakrishnan C, Gaitonde S, Mittal G, Pathan E, Gokhale NS, et al. Rheumatoid corneal melt. Rheumatology (Oxford) 2002;41:705-6.

10 Scott DG, Bacon PA. Intravenous cyclophosphamide plus methylprednisolone in treatment of systemic rheumatoid arthritis. Am J Med 1984;76:377-84.

\section{Therapeutic use of infliximab in sight threatening uveitis: retrospective analysis of efficacy, safety, and limiting factors}

\section{B Bodaghi, E Bui Quoc, B Wechsler, T H C Tran, N Cassoux, D Le Thi Huong, O Chosidow, $S$ Herson, J-C Piette, $\mathrm{P}$ LeHoang}

A nti-tumour necrosis factor (TNF) molecules have become a valuable addition to the therapeutic armamentarium for patients with severe uveitis. ${ }^{1-7}$ A retrospective study was conducted from June 2001 to June 2003 including patients with a refractory uveitis, resistant to corticosteroids and conventional immunosuppressive drugs. Patients were screened for infectious conditions. Informed consent was obtained in all cases. Treatment was given if patients were suffering. Infliximab was initially given at a dose of $5 \mathrm{mg} / \mathrm{kg}$, renewed at weeks 2, 6, and every 8 weeks, and then every 10-12 weeks when uveitis had been controlled for more than 6 months. Prednisone and immunosuppressive drugs were tapered progressively if there was no evidence of ocular inflammation. Dose escalation $(10 \mathrm{mg} / \mathrm{kg}$ ) was proposed when relapse or secondary resistance occurred.

Twelve patients (21 eyes) were included in this study (mean age of 35 years). Uveitis was bilateral in 10/12 (83\%) cases. Mean duration of disease before starting infliximab was 7 years (range 2-20). Rapid control of uveitis was achieved in all cases. Improvement by six lines of vision and three lines of vision was obtained respectively in five and 10 patients at the end of follow up (table 1). Systemic disease was controlled in all cases. Mean follow up was 17.4 months (range 8-30). Relapses occurred in four (33\%) cases after a mean period of 57.3 weeks (range 14-108). Of these four patients, two had Behçet's disease (fig 1), one had ankylosing spondylitis, and one idiopathic panuveitis. Relapses occurred when infusions were performed less frequently than every 8 weeks (between 10 and 12 weeks). Finally, immunosuppressive drugs were discontinued and corticosteroids were tapered in four $(33 \%)$ cases; methotrexate and low dose corticosteroids were continued in five $(42 \%)$ cases. Azathioprine or mycophenolate mofetil were necessary in three patients. No serious adverse event occurred in this series.

The $5 \mathrm{mg} / \mathrm{kg}$ dose of infliximab is effective and has been used in most of the previous studies on uveitis. Although his study was not controlled, choosing patients refractory to a combination of high dose steroids and immunosuppressive drugs, rules out an overestimation of the benefit of the drug. The use of anti-TNF $\alpha$ after failure of other drugs is a promising alternative, but long term efficacy of infliximab must be discussed. Its high cost still limits its use. Potential adverse effects need close monitoring before and during treatment. ${ }^{8-10}$ Long term effects of the treatment are still unknown. Meanwhile, we recommend the use of anti-TNF agents after the failure of conventional immunosuppressive drugs (fig 2). The effect of infliximab on acute inflammatory ocular lesions is spectacular. As a rescue strategy, its use may be discussed in severe forms of retinal necrosis associated 


\begin{tabular}{|c|c|c|c|c|c|c|c|c|c|}
\hline $\begin{array}{l}\text { Patier } \\
\text { No }\end{array}$ & Sex & $\begin{array}{l}\text { Age } \\
\text { (years) }\end{array}$ & $\begin{array}{l}\text { Duration } \\
\text { of uveitis } \\
\text { (years) }\end{array}$ & Clinical presentation & $\begin{array}{l}\text { Aetiology/anatomical } \\
\text { localisation }\end{array}$ & $\begin{array}{l}\text { alTreatment before } \\
\text { infliximab }\end{array}$ & $\mathbf{F}$ & $\begin{array}{l}\text { Evolution/ } \\
\text { Initial/final VA }\end{array}$ & $\begin{array}{l}\text { Treatment at last } \\
\text { examination }\end{array}$ \\
\hline 1 & $M$ & 33 & 7 & $\begin{array}{l}\text { OD: macular oedema } \\
\text { and vitritis } \\
\text { OS: macular necrosis }\end{array}$ & $\mathrm{BD} / \mathrm{panU}$ & $\begin{array}{l}\text { Prednisone, pentoxifylline, } \\
\text { cyclophosphamide, } \\
\text { interferon } \alpha 2 a \text {, } \\
\text { azathioprine }\end{array}$ & 28 & $\begin{array}{l}\text { OD: Rapid regression } \\
\text { of macular oedema } \\
\text { and vitritis } \\
\text { OS unchanged. } \\
\text { Relapses at weeks } 82 \\
\text { and } 108 \\
\text { OD } 20 / 200 \text { OS } 20 / \\
400 \\
\text { OD 20/25 OS 20/ } \\
400\end{array}$ & $\begin{array}{l}\text { Prednisone, MTX, } \\
\text { infliximab }\end{array}$ \\
\hline 2 & $\mathrm{~F}$ & 38 & 4 & $\begin{array}{l}\text { OD: macular oedema } \\
\text { OS: macular necrosis }\end{array}$ & $\mathrm{BD} / \mathrm{PU}$ & $\begin{array}{l}\text { Prednisone, pentoxifylline, } \\
\text { interferon } \alpha 2 a \text {, azathioprine, } \\
\text { cyclophosphamide }\end{array}$ & 30 & $\begin{array}{l}\text { Regression of right } \\
\text { macular oedema } \\
\text { OD 20/200 OS LP } \\
\text { OD 20/20 OS LP }\end{array}$ & $\begin{array}{l}\text { Prednisone, } \\
\text { infliximab }\end{array}$ \\
\hline 3 & $\mathrm{~F}$ & 21 & 8 & $\begin{array}{l}\text { OD: enucleated } \\
\text { OS: macular necrosis }\end{array}$ & $\mathrm{BD} / \mathrm{PU}$ & $\begin{array}{l}\text { Prednisone, } \\
\text { cyclophosphamide, } \\
\text { interferon } \alpha 2 a \text {, } \\
\text { azathioprine }\end{array}$ & 29 & $\begin{array}{l}\text { Regression of } \\
\text { inflammatory signs } \\
\text { OS } 20 / 40 \\
\text { OS } 20 / 20\end{array}$ & $\begin{array}{l}\text { Prednisone, } \\
\text { infliximab }\end{array}$ \\
\hline 4 & M & 30 & 2 & $\begin{array}{l}\text { Bilateral vasculitis, } \\
\text { haemorrhagic retinitis, } \\
\text { vitritis, macular oedema }\end{array}$ & $\mathrm{BD} / \mathrm{panU}$ & $\begin{array}{l}\text { Prednisone, interferon } \\
\alpha 2 a\end{array}$ & 16 & $\begin{array}{l}\text { Initial improvement } \\
\text { but relapses at } \\
\text { weeks } 14 \text { and } 40 \\
\text { OD } 20 / 60 \text { OS } \\
20 / 40 \\
\text { OD } 20 / 25 \text { OS } \\
20 / 25\end{array}$ & $\begin{array}{l}\text { Infliximab } \\
(10 \mathrm{mg} / \mathrm{kg}) \text {, } \\
\text { mycophenolate } \\
\text { mofetil, MTX, } \\
\text { prednisone }\end{array}$ \\
\hline 5 & M & 20 & 2 & $\begin{array}{l}\text { Bilateral vasculitis, } \\
\text { haemorrhagic retinitis, } \\
\text { vitritis, macular oedema }\end{array}$ & $\mathrm{BD} / \mathrm{panU}$ & $\begin{array}{l}\text { Prednisone, azathioprine, } \\
\text { interferon } \alpha 2 a \text {, rifampin }\end{array}$ & 8 & $\begin{array}{l}\text { Efficacy but still } \\
\text { receiving prednisone } \\
\text { and methotrexate } \\
\text { OD } 20 / 100 \text { OS } \\
20 / 200 \\
\text { OD } 20 / 20 \text { OS } 20 / 20\end{array}$ & $\begin{array}{l}\text { Infliximab, MTX, } \\
\text { prednisone } \\
0\end{array}$ \\
\hline 6 & M & 45 & ( & $\begin{array}{l}\text { OD: vision lost due to } \\
\text { chronic inflammation } \\
\text { and glaucoma } \\
\text { OS: inflammation and } \\
\text { ocular hypertension }\end{array}$ & $\begin{array}{l}\text { Ankylosing } \\
\text { spondylitis, HLA- } \\
\text { B27+/panU }\end{array}$ & $\begin{array}{l}\text { Prednisone, MTX, } \\
\text { cyclophosphamide, } \\
\text { azathioprine }\end{array}$ & 24 & $\begin{array}{l}\text { Relapse at week } 54 \\
\text { Restarted } \\
\text { immunosuppressive } \\
\text { treatment } \\
\text { OD NLP OS } 20 / 40 \\
\text { OD NLP OS } 20 / 20\end{array}$ & $\begin{array}{l}\text { Prednisone, } \\
\text { azathioprine }\end{array}$ \\
\hline 7 & M & 38 & 6 & $\begin{array}{l}\text { Unilateral non- } \\
\text { granulomatous anterior } \\
\text { uveitis and refractory } \\
\text { glaucoma }\end{array}$ & $\begin{array}{l}\text { Ankylosing } \\
\text { spondylitis, HLA- } \\
\text { B27+/AU }\end{array}$ & $\begin{array}{l}\text { Prednisone, MTX, } \\
\text { ciclosporin A }\end{array}$ & 9 & $\begin{array}{l}\text { Control of ocular } \\
\text { and articular } \\
\text { inflammation } \\
\text { OD } 20 / 50 \text { OS } 20 / 20 \\
\text { OD } 20 / 20 \text { OS } 20 / 20\end{array}$ & $\begin{array}{l}\text { Infliximab, MTX, } \\
\text { prednisone } \\
0 \\
0\end{array}$ \\
\hline 8 & $\mathrm{~F}$ & 42 & i & $\begin{array}{l}\text { OD: Normal. } \\
\text { OS: anterior chamber } \\
\text { inflammation, macular } \\
\text { oedema, epiretinal } \\
\text { membrane, secondary } \\
\text { glaucoma }\end{array}$ & Psoriasis/panU & Prednisone, MTX & 16 & $\begin{array}{l}\text { No relapse } \\
\text { Low dose prednisone, } \\
\text { cataract surgery } \\
\text { OD } 20 / 20 \text { OS 20/60 } \\
\text { V }\end{array}$ & $\begin{array}{l}\text { Infliximab, } \\
\text {, prednisone } \\
0\end{array}$ \\
\hline 9 & $\mathrm{~F}$ & 57 & 16 & $\begin{array}{l}\text { Bilateral non } \\
\text { granulomatous } \\
\text { panuveitis with posterior } \\
\text { synechiae, secondary } \\
\text { glaucoma, vitritis, } \\
\text { macular oedema }\end{array}$ & Psoriasis/panU & Prednisone, MTX & 12 & $\begin{array}{l}\text { No relapse } \\
\text { Cataract surgery, } \\
\text { trabeculectomy OD } \\
\text { and OS } \\
\text { OD } 20 / 60 \text { OS } \\
20 / 80 \\
\text { OD } 20 / 20 \text { OS } \\
20 / 30\end{array}$ & $\begin{array}{l}\text { Infliximab, } \\
\text { prednisone, } \\
\text { azathioprine }\end{array}$ \\
\hline 10 & $\mathrm{~F}$ & 34 & 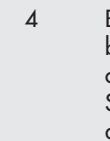 & $\begin{array}{l}\text { Bilateral panuveitis, } \\
\text { bilateral macular } \\
\text { oedema } \\
\text { Seronegative } \\
\text { ankylosing spondylitis }\end{array}$ & $\begin{array}{l}\text { B27- } \\
\text { spondyloarthropathy } \\
\text { /panU }\end{array}$ & Prednisone, MTX & 9 & $\begin{array}{l}\text { Regression of } \\
\text { inflammatory signs } \\
\text { and macular oedema } \\
\text { OD 20/50 OS } 20 / 40 \\
\text { OD } 20 / 30 \text { OS } 20 / 25\end{array}$ & $\begin{array}{l}\text { Infliximab, MTX, } \\
\text { prednisone } \\
0 \\
5\end{array}$ \\
\hline 11 & M & 43 & 20 & $\begin{array}{l}\text { Right eye lost through } \\
\text { neovascular glaucoma } \\
\text { Left eye, papillitis, } \\
\text { macular oedema, } \\
\text { vitritis, retinal necrosis }\end{array}$ & $\begin{array}{l}\text { Idiopathic } \\
\text { panU }\end{array}$ & $\begin{array}{l}\text { Prednisone, azathioprine, } \\
\text { cyclophosphamide }\end{array}$ & 16 & $\begin{array}{l}\text { Regression of } \\
\text { inflammatory signs } \\
\text { and macular oedema } \\
\text { Relapse at week } 46 \\
\text { OD NLP OS CF } \\
\text { OD NLP OS 20/40 }\end{array}$ & $\begin{array}{l}\text { Infliximab, MTX, } \\
\text { prednisone }\end{array}$ \\
\hline 12 & $\mathrm{~F}$ & 16 & 7 & $\begin{array}{l}\text { OD: papillitis, macular I } \\
\text { oedema, vitritis } \\
\text { OS: macular oedema, } \\
\text { vitritis, optic atrophy }\end{array}$ & Idiopathic panU & $\begin{array}{l}\text { Prednisone, azathioprine, } \\
\text { interferon } \alpha 2 a\end{array}$ & 12 & $\begin{array}{l}\text { Regression of } \\
\text { inflammatory signs } \\
\text { and macular oedema } \\
\text { Cataract surgery } \\
\text { OD } 20 / 400 \text {, OS CF } \\
\text { OD } 20 / 40 \text { OS } \\
20 / 200\end{array}$ & $\begin{array}{l}\text { Infliximab, } \\
\text { prednisone }\end{array}$ \\
\hline
\end{tabular}

\footnotetext{
$\mathrm{OD}$, right eye; $\mathrm{OS}$, left eye, $\mathrm{BD}$, Behçet's disease; panU, panuveitis; $\mathrm{PU}$, posterior uveitis; $\mathrm{AU}$, anterior uveitis; $\mathrm{F}$, follow up (months); CF, counting fingers; MTX methotrexate.
} 


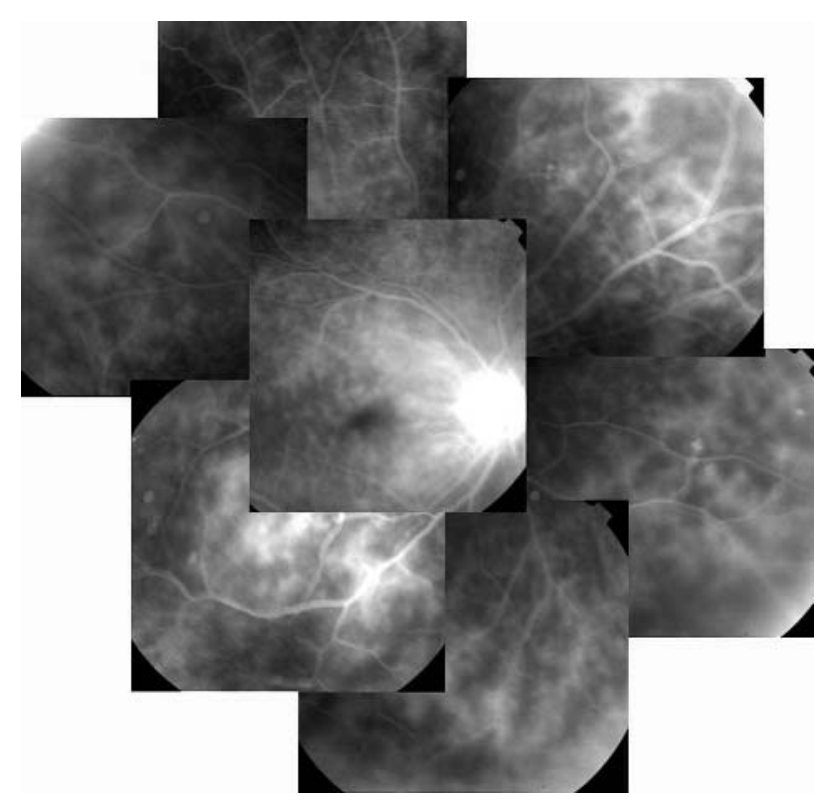

Figure 1 Early relapse of posterior uveitis in a patient with Behçet's disease, 6 weeks after the third infusion of infliximab. Fluorescein angiography showing diffuse retinal choriocapillaropathy, macular oedema, and papillitis.

with Behçet's disease, to control the acute phase of the inflammatory process. It will be possible to discuss a further shift to standard immunosuppressive drugs when the acute phase of the disease has been controlled. Furthermore, association of infliximab and other standard immunosuppressive drugs allows the anti-TNF dosage to be decreased. This should be taken into consideration to prevent immunogenicity against the drug, inducing secondary resistance. Tapering of corticosteroids and discontinuation of immunosuppressive drugs must be achieved cautiously, in order to prevent further relapses.

It is difficult to consider infliximab as a chronic long term monotherapy. Owing to the rapidity of action, it has to be administered earlier in the course of the disease, to spare steroids and to facilitate the action of other immunosuppressive drugs. Induction treatment with infliximab has an increased likelihood of a sustained response over a long term period if infusions are continued every 8 weeks. However the optimal dose, rhythm, and duration of infliximab infusions need to be standardised. Our data indicate the need for larger controlled trials before drawing up further adapted guidelines.

\section{Authors' affiliations}

B Bodaghi, E Bui Quoc, T H C Tran, N Cassoux, P LeHoang, Department of Ophthalmology, University of Paris VI, Pitié-Salpêtrière Hospital, 4783, boulevard de l'Hôpital, 75651 Paris cedex 13, France B Wechsler, D Le Thi Huong, O Chosidow, S Herson, J-C Piefte, Department of Internal Medicine, University of Paris VI, Pitié-Salpêtrière Hospital, 47-83, boulevard de l'Hôpital, 75651 Paris cedex 13, France

Correspondence to: Professor P LeHoang, bahram.bodaghi@ psl.ap-hop-paris.fr

Accepted 1 November 2004

\section{REFERENCES}

1 Murphy CC, Greiner K, Plskova J, Duncan L, Frost A, Isaacs JD, et al. Neutralizing tumor necrosis factor activity leads to remission in patients with refractory noninfectious posterior uveitis. Arch Ophthalmol 2004; 122:845-51.

2 El-Shabrawi Y, Hermann J. Anti-tumor necrosis factor-alpha therapy with infliximab as an alternative to corticosteroids in the treatment of human leukocyte antigen B27-associated acute anterior uveitis. Ophthalmology 2002; 109:2342-6.

3 Joseph A, Raj D, Dua HS, Powell PT, Lanyon PC, Powell RJ. Infliximab in the treatment of refractory posterior uveitis. Ophthalmology 2003;1 10:1449-53.

4 Mansour AM. Infliximab treatment of posterior uveitis. Ophthalmology 2004;111:197-8, author reply 198.

5 Rosenbaum JT, Smith JR, Levinson RD, Holland GN, Jabs DA, Robinson MR, et al. Anti-TNF therapy for eye involvement in spondyloarthropathy. Differential efficacy of tumor necrosis factor inhibition in the management of inflammatory eye disease and associated rheumatic disease. Clin Exp Rheumatol 2002;20(suppl 28):S143-5.

6 Sfikakis PP, Kaklamanis PH, Elezoglou A, Katsilambros N, Theodossiadis PG, Papaefthimiou $S$, et al. Infliximab for recurrent, sight-threatening ocular inflammation in Adamantiades-Behcet disease. Ann Intern Med 2004; 140:404-6

7 Smith JR, Levinson RD, Holland GN, Jabs DA, Robinson MR, Whitcup SM, et al. Differential efficacy of tumor necrosis factor inhibition in the management of inflammatory eye disease and associated rheumatic disease. Arthritis Rheum 2001;45:252-7

8 Fleischmann R, lqbal I, Nandeshwar P, Quiceno A. Safety and efficacy of disease-modifying anti-rheumatic agents: focus on the benefits and risks of etanercept. Drug Saf 2002;25:173-97.

9 Lim WS, Powell RJ, Johnston ID. Tuberculosis and treatment with infliximab. N Engl J Med 2002;346:623-6.

10 Brown SL, Greene MH, Gershon SK, Edwards ET, Braun MM. Tumor necrosis factor antagonist therapy and lymphoma development: twenty-six cases reported to the Food and Drug Administration. Arthritis Rheum 2002;46:3151-8.

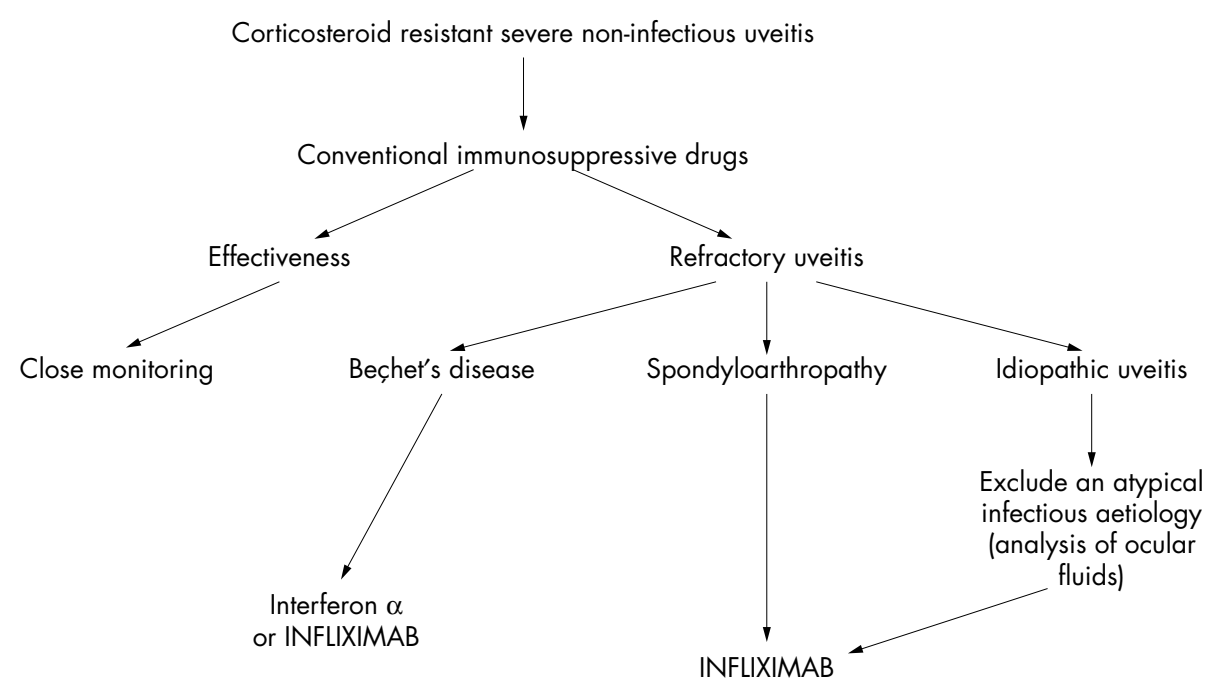

Figure 2 Therapeutic escalation in patients with severe refractory uveitis. 


\title{
Systemic mastocytosis: a rare cause of osteoporosis and its response to bisphosphonate treatment
}

\author{
A Y N Lim, A J K Ostor, S Love, A J Crisp
}

Ann Rheum Dis 2005;64:965-966. doi: 10.1136/ard.2004.029116

$M$ astocytosis comprises a heterogeneous group of disorders of mast cell proliferation. Infiltration of multiple organs by mast cells may occur, including skin and bone, with cutaneous and systemic variants being well described. There are few reports of the treatment of osteoporosis, a secondary manifestation of systemic mastocytosis (SM). ${ }^{1-3}$ We undertook a retrospective analysis of six patients with osteoporosis associated with SM treated with bisphosphonates.

\section{CASE REPORTS}

The mean age of the patients was 58 years (range 40-70) and the mean duration of SM was 8 years (range 3-13). All patients had a past history of urticaria pigmentosa and had presented to their general practitioner with back pain. Four patients had vertebral crush fractures on plain radiography. Isotope bone scans in the remaining two patients showed diffuse skeletal uptake consistent with marrow infiltration. Bone marrow biopsy in all patients confirmed mast cell infiltration. All patients had mast cell mediator related symptoms (flushing, wheezing, diarrhoea with abdominal pain, pruritus, bone pain) and raised total serum tryptase levels persistently $>20 \mathrm{ng} / \mathrm{ml}$. This fulfilled the diagnostic criteria for SM, defined by multifocal histological lesions in the bone marrow or other extracutaneous organs (major criteria) together with cytological and biochemical signs (minor criteria) of systemic disease. ${ }^{4}$ Tryptase levels correlate with the clinical severity of SM, ${ }^{5}$ and we used this to monitor disease activity.

Treatment was started with bisphosphonates (annual intravenous pamidronate followed by alendronate in five patients, alendronate only in the sixth patient). No further fractures developed despite absence of specific treatment for mast cell proliferation. All patients had a subjective improvement in pain after bisphosphonate treatment. Hologic bone mineral density (BMD) measurements were assessed at baseline and at 1-2 yearly intervals thereafter. BMD in the lumbar spine rose in all patients from baseline; two patients
(Nos 1 and 2) were excluded owing to multiple lumbar vertebral fractures. Total hip BMD rose in three patients and stabilised in the other three (table 1).

\section{DISCUSSION}

Disorders of mast cells, derived from the multipotent haematopoietic stem cell are rare. Cutaneous mastocytosis without systemic involvement manifests in childhood as urticaria pigmentosa and spontaneous regression occurs during puberty. Symptoms of SM are related to the release of mast cell mediators, including histamine, prostaglandins, leucotrienes, and proteases, with bone pain occurring frequently. The radiological findings in SM include diffuse osteoporosis with vertebral fractures and/or a combination of osteosclerotic and osteolytic lesions, primarily affecting the axial skeleton and ends of long bones. Solitary lesions (mastocytomas) may cause localised pain.

The cellular and pathophysiological mechanisms leading to osteoporosis in SM are poorly understood. Mast cells infiltrating bone marrow may have an inhibitory effect on the coupling of bone formation and resorption, with the balance in favour of the latter. It is unlikely that bone resorption is caused directly by mast cell release of heparin, prostaglandin $\mathrm{D}_{2}$, and tryptase. ${ }^{16}$

SM has been reported to account for a greater than expected cause of osteoporosis in the younger population. ${ }^{7}$ Indeed, back pain secondary to osteoporotic vertebral fractures may be the major presenting symptom of SM. BMD stabilised without the occurrence of further fractures in our patients. Fracture reduction is due not only to inhibition of osteoclasts by bisphosphonates but their ability to reduce the activation frequency and birth rates of new bone remodelling units and to enhance osteon mineralisation. ${ }^{8}$ Musculoskeletal pain in mastocytosis may be present in up to $28 \%$ of patients and is difficult to manage. ${ }^{9}$ Interestingly, our patients reported improvement in bone pain after bisphosphonate treatment.

In conclusion, SM, although rare, should be included in the differential diagnosis of idiopathic osteoporosis because of its

\begin{tabular}{|c|c|c|c|c|c|c|}
\hline & \multicolumn{6}{|l|}{ Patient No } \\
\hline & 1 & 2 & 3 & 4 & 5 & 6 \\
\hline Age & 70 & 67 & 54 & 58 & 40 & 61 \\
\hline Sex & $\mathrm{F}$ & $\mathrm{F}$ & M & $\mathrm{F}$ & $\mathrm{F}$ & $\mathrm{F}$ \\
\hline BM biopsy & $\begin{array}{l}\text { Mast cell } \\
\text { infiltration }\end{array}$ & $\begin{array}{l}10 \% \text { Mast cell } \\
\text { infiltration }\end{array}$ & $\begin{array}{l}\text { Focal clusters of } \\
\text { mast cells }\end{array}$ & $\begin{array}{l}\text { Mast cell } \\
\text { infiltration }\end{array}$ & $\begin{array}{l}\text { Mast cell } \\
\text { infiltration }\end{array}$ & $\begin{array}{l}20 \% \text { Mast cell } \\
\text { infiltration }\end{array}$ \\
\hline $\begin{array}{l}\text { Treatment duration with IV } \\
\text { pamidronate }\end{array}$ & $\begin{array}{l}1992-2000 \\
\text { annual doses }\end{array}$ & $\begin{array}{l}1990-2000 \\
\text { annual doses }\end{array}$ & $\begin{array}{l}\text { 1994-1998 } \\
\text { annual doses }\end{array}$ & $\begin{array}{l}2000 \\
\text { single dose }\end{array}$ & Not treated & $\begin{array}{l}2001-2003 \\
\text { three doses }\end{array}$ \\
\hline $\begin{array}{l}\text { Cumulative dose of } \\
\text { pamidronate (mg) }\end{array}$ & 555 & 915 & 360 & 90 & Not treated & 270 \\
\hline $\begin{array}{l}\text { Year alendronate started } \\
\text { L1-4 spine T score before }\end{array}$ & 2000 until current & 2001 until current & 1998 until current & 2001 until current & 2001 until current & 2001 for 6 months \\
\hline treatment & -1.49 & -4.05 & -4.54 & -4.07 & -2.8 & -0.76 \\
\hline $\begin{array}{l}\text { L1-4 spine T score in } 2003 \\
\text { Total hip T score before }\end{array}$ & -2.0 & -3.27 & -3.34 & -3.29 & -3.0 & -0.45 \\
\hline treatment & -1.7 & -3.5 & -3.29 & -1.16 & -1.8 & +0.23 \\
\hline Total hip T score in 2003 & -1.4 & -3.07 & -2.36 & -1.17 & -1.8 & +0.23 \\
\hline
\end{tabular}


significant morbidity. Bisphosphonates are effective in SM for osteoporosis and have a role in the associated refractory bone pain.

\section{Authors' affiliations}

A Y N Lim, A J K Ostor, S Love, A J Crisp, Departments of Rheumatology and Metabolic Bone Diseases, Addenbrooke's Hospital, Cambridge CB2 2QQ, UK

Correspondence to: Dr A Lim, Rheumatology Department, Norfolk and Norwich University Hospital, Norwich NR4 7UY, UK; anita.lim@doctors.org.uk

Accepted 9 October 2004

\section{REFERENCES}

1 Cundy T, Beneton MNC, Darby AJ, Marshall WJ, Kanis JA. Osteopenia in systemic mastocytosis: natural history and responses to treatment with inhibitors of bone resorption. Bone 1987;8:149-55.
2 Marshall A, Kavanagh T, Crisp AJ. The effect of pamidronate on lumbar spine bone density and pain in osteoporosis secondary to systemic mastocytosis. Br J Rheumatol 1997:36:393-6.

3 Brumsen C, Hamdy NAT, Papapoulos SE. Osteoporosis and bone marrow mastocytosis: dissociation of skeletal responses and mast cell activity during long term bisphophonate therapy. J Bone Miner Res 2002; 17:567-9.

4 Valent P, Horny H-P, Escribano L, Longley BJ, Li CY, Schwartz LB, et al. Diagnostic criteria and classification of mastocytosis: a consensus proposal. Leuk Res 2001;25:603-25.

5 Sperr WR, Jordan J-H, Fiegl M, Escribano L, Bellas C, Dirnhofer S, et al. Serum tryptase levels in patients with mastocytosis: correlation with mast cell burden and implication for defining the category of disease. Int Arch Allergy Immunol 2002;128:136-41.

6 Chines A, Pacifici R, Avioli LV, Teitelbaum SL, Korenblat PE. Systemic mastocytosis presenting as osteoporosis: a clinical and histomorphometric study. J Clin Endocrinol Metab 1991:72:140-4.

7 Delling G, Ritzel H, Werner M. Histological characteristics and prevalence of secondary osteoporosis in systemic mastocytosis. A retrospective analysis 158 cases. Pathologe 2001;22:132-40.

8 Russell RG, Rogers MJ. Bisphosphonates: from the laboratory to the clinic and back again. Bone 1999:25:97-106.

9 Johnstone PAS, Mican JM, Metcalfe DD, Delaney TF. Radiotherapy of refractory bone pain due to systemic mast cell disease. Am J Clin Oncol 1994; 17:328-30.

\section{Frostbite arthritis}

\section{J E Kahn, O Lidove, J D Laredo, O Blétry}

A 46 year old black woman, born in Haiti, was admitted in 1999 owing to bilateral and symmetric arthritis of the hands. Her past history was unremarkable. She had lived in New York in the 1970s, where she sustained an episode of severe frostbite in 1977 while staying outside for 1 hour at a temperature of $-20^{\circ} \mathrm{C}$ without protection. Frostbite affected all fingers but not the thumbs, requiring admission to hospital for 11 days (amputation of some fingers was discussed at this time).

She had complained about arthritis affecting the interphalangeal (IP) joints since 1994, without extra-articular involvement or fever. Progressive joint deformations appeared at this time. Clinical examination was normal except for proximal IP joint deformation.

Routine laboratory tests, immunological tests (antinuclear antibodies, rheumatoid factor, antineutrophil cytoplasmic antibodies, complement), seric tests (HIV, HTLV-1, TPHA-VDRL), proteins, and haemoglobin electrophoresis were normal or negative.

Plain radiographs of the hands showed an erosive arthritis with subchondral osteosclerosis and large punched-out cystic defects affecting all proximal and some of the distal IP joints and metacarpophalangeal joints (fig 1). A technetium-99m scintigraphy showed early and massive increased uptake of the radiologically affected joints. A radiographic survey of the skeleton and pulmonary $x$ ray findings were normal. A synovial biopsy and a bone biopsy of a lytic lesion of the second phalange of the third left finger were non-conclusive.

Treatment with non-steroidal anti-inflammatory (NSAIDs) drugs was unsuccessful. Significant clinical improvement was obtained with clodronic acid, $800 \mathrm{mg}$ twice a day. In 2004, radiographs of hands showed a moderate extension of punched-out cystic defects, without progression of joint deformations. Immunological tests remain negative.
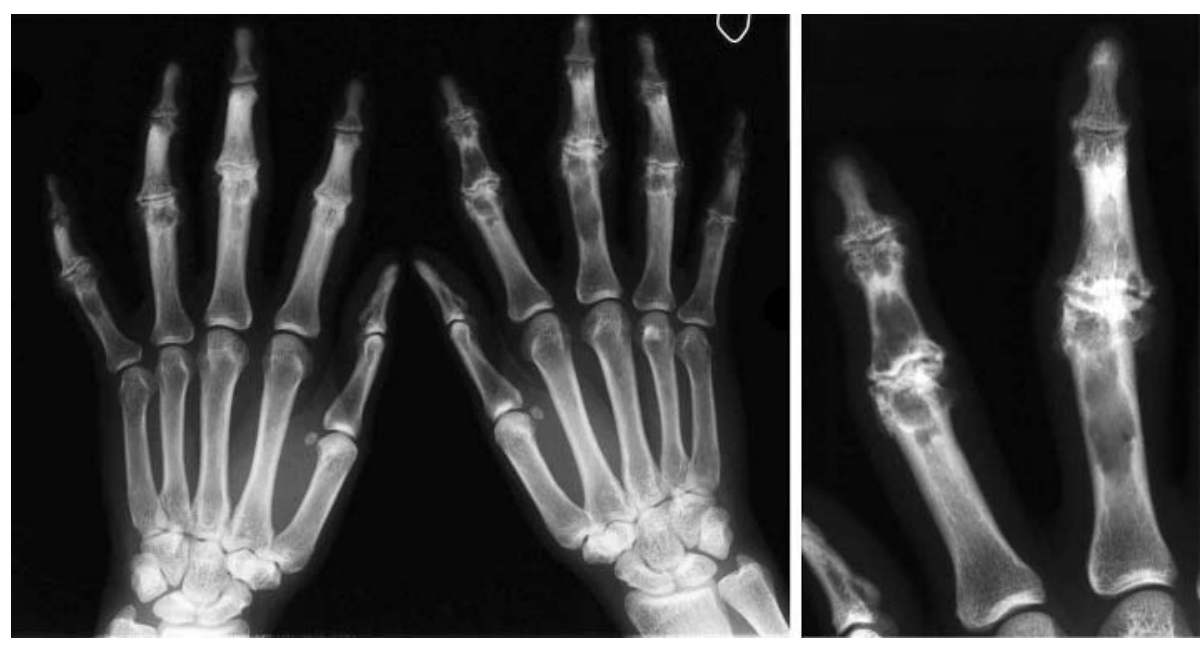

Figure 1 Erosive arthritis with subchondral osteosclerosis and large punched-out cystic defects affecting all proximal and some of the distal IP joints. 


\section{DISCUSSION}

Initially described in the military population, frostbite is also common in people with psychiatric disturbance, intoxication, or unplanned circumstances leading to cold exposure (as in our case).

Clinical and radiological changes mimic those of osteoarthritis. ${ }^{1-3}$ A clinical and radiological idiosyncrasy is the preservation of both thumbs and metacarpophalangeal joints. ${ }^{14}$ Sparing of the thumb is characteristic, although not invariable, and can be attributed to clenching of the fist with the thumb clasped in the palm during cold exposure. The presence of large subchondral cysts in our patient, probably consecutive to bone infarcts, helps in differentiating frostbite arthritis from osteoarthritis. Early diagnosis can be suspected by ${ }^{99 \mathrm{~m}} \mathrm{Tc}$ scintigraphy in the first days after exposure to cold, but hyperfixation could persist several years after, as reported in this observation.

The time intervals between frost injury and clinical symptoms are variable-from 3 to 10 years ( 17 years in our case). Frostbite results from exposure to cold air usually at a temperature below $-13^{\circ} \mathrm{C}\left(8^{\circ} \mathrm{F}\right)$. The development and progression of frostbite injuries are directly related to abnormality in circulation (thrombosis, vasoconstriction).

A pathophysiological study has shown marked similarities in inflammatory processes between thermal burns and ischaemia/reperfusion injury due to cold exposure. Evidence of the role of thromboxanes and prostaglandins has resulted in more active approaches to the medical treatment of frostbite wounds. ${ }^{5}$ Initial treatments are debatable: vasodilators, hyperbaric oxygen, thrombolysis, or surgery, when necessary. At a chronic stage, treatment of frostbite arthritis with NSAIDs or steroids at low dosage has been suggested. Clodronic acid was proposed because of the known anodyne effect of bisphosphonates in some cases of rheumatism, but, to our knowledge, there is no report of use of bisphosphonates in frostbite arthritis.

In conclusion, patients with distal arthritis should be carefully questioned for a history of exposure to cold, and frostbite arthritis should be considered in the differential diagnosis of unexplained, seronegative arthritis of hands. Clinical and radiological changes mimicked those of osteoarthritis, but the presence of giant subchondral cysts, unusual in osteoarthritis, may suggest the diagnosis.

\section{Authors' affiliations}

J E Kahn, O Blétry, Department of Internal Medicine, Foch Hospital, 40 rue Worth, 92150 Suresnes, France

O Lidove, Department of Internal Medicine, Bichat-Claude Bernard Hospital, 46 rue Henri Huchard, 75877 Paris Cedex 18, France

J D Laredo, Department of Skeletal Radiology, Lariboisière Hospital, 2 rue Ambroise-Paré, 75475 Paris Cedex 10, France

Correspondence to: Dr J E Kahn, je.kahn@hopital-foch.org

Accepted 21 November 2004

\section{REFERENCES}

1 Resnick D. Thermal and electrical injuries. In: Diagnosis of bone and joint disorders. Philadelphia: Saunders, 1995:3264-75.

2 Glick R, Parhami N. Frostbite arthritis. J Rheumatol 1979:6:456-60.

3 Turner M, Smith RW. Unusual and memorable. Erosive nodal osteoarthritis after frostbite. Ann Rheum Dis 1998;57:271.

4 Kemp SS, Dalinka MK, Schumacher HR. Acro-osteolysis. Etiologic and radiological considerations. JAMA 1986;255:2058-61.

5 Murphy JV, Banwell PE, Roberts AH, McGrouther DA. Frostbite: pathogenesis and treatment. J Trauma 2000;48:171-8. 